\title{
Non-tariff measures a trade barrier for developing countries' agricultural processed products exports
}

\author{
Sushil Mohan \\ Brighton Business School, University of Brighton, UK \\ s.mohan@brighton.ac.uk
}

\begin{abstract}
The paper analyses the trade barriers that thwart diversification efforts of developing countries into exports of value-added agricultural processed products. It examines the extent to which non-tariff measures act as market access barriers that constrain agricultural processed products exports from developing countries. The analysis shows that the prevalence of non-tariff measures (including domestic non-tariff measures) limit the ability of developing countries to increase their agricultural processed exports. This has important policy implications in terms of the emphasis that trade negotiators and policy planners should place on addressing non-tariff measures both in the domestic and foreign markets.
\end{abstract}

KEYWORDS: Agricultural processed products exports, developing countries, non-tariff measures

\section{Introduction}

Public enterprises that have traditionally been oriented towards domestic market are increasingly competing with private firms in the global market place. In some sectors hey are facing problems due to real or imagined government subsidy. Moreover in many developing countries public enterprises play an important role in supporting the government negotiators trying to dismantle trade barriers.

The agricultural sector is relatively more important for the economy of many developing countries (hereafter DCs). It remains the largest source of employment, GDP, exports and foreign exchange earnings in most DCs. It usually accounts for 50-70 percent of the national GDP in DCs. According to the Food and Agriculture organisation of the United Nations (FAO), DCs are the major producers of agricultural products - in general, they account for more than two-third of total world 
agricultural production and the remaining coming from developed countries. Despite this, developed countries account for a much higher share of the total world agricultural exports, with about two-thirds of total exports coming from developed countries and the remaining from DCs (FAOSTAT, 2019).

A reason for DCs' low share in total world agricultural exports is their low share in world exports of agricultural processed (final) products which normally have a higher value-added than primary agricultural products. Table 1 shows that in 2010-2014 agricultural processed products exports averaged 46 percent of total world agricultural exports and the share of DCs in total agricultural processed products exports was only 39 percent compared to 61 percent for developed countries.

Table 1: Exports of processed (final) agricultural products, 2010-14

\begin{tabular}{ccccccc}
\hline & $\begin{array}{c}\text { Total world exports of } \\
\text { agricultural final } \\
\text { products }\end{array}$ & \multicolumn{2}{c}{$\begin{array}{c}\text { Composition of world } \\
\text { exports of agricultural final } \\
\text { products (USD billion) }\end{array}$} & \multicolumn{2}{c}{$\begin{array}{c}\text { Share in the world exports } \\
\text { of agricultural final } \\
\text { products }(\%)\end{array}$} \\
\hline Year & $\begin{array}{c}\text { Value } \\
\text { (US\$ } \$\end{array}$ & $\begin{array}{c}\text { Share in total } \\
\text { agricultural } \\
\text { billion) }\end{array}$ & $\begin{array}{c}\text { Developing } \\
\text { exports (\%) }\end{array}$ & $\begin{array}{c}\text { Developed } \\
\text { countries } \\
\text { countries }\end{array}$ & $\begin{array}{c}\text { Developing } \\
\text { countries }\end{array}$ & $\begin{array}{c}\text { Developed } \\
\text { countries }\end{array}$ \\
\hline 2010 & 605 & 46 & 228 & 377 & 38 & 62 \\
2011 & 731 & 46 & 284 & 446 & 39 & 61 \\
2012 & 732 & 46 & 292 & 440 & 40 & 60 \\
2013 & 776 & 47 & 309 & 467 & 40 & 60 \\
2014 & 784 & 47 & 309 & 475 & 39 & 61 \\
\hline
\end{tabular}

Note: See Appendix 1 for classification for separating agricultural processed products.

Table 1 highlights that DCs' are lagging in exports of agricultural processed products. For example, the share of developed countries in world exports of roasted coffee is around 93 percent even though an almost negligible amount of coffee is produced in developed countries. For tea, DCs are the main producers and exporters of bulk tea. This is an area where DCs have increased their share of processed exports over the years - they export 71 percent of packaged tea in contrast to 29 percent from developed countries. In the case of cocoa, the share of DCs in world exports of cocoa beans is around 90 percent, while the share in world exports of cocoa paste, cocoa powder is only 46 and 33 percent respectively. When it comes to chocolates and other cocoa products, DCs share is only 17 percent. Similarly, developed countries have a higher share in world exports of manufactured tobacco (67 percent) and processed rubber (62 percent). In the case of sugar, developed countries produce relatively small amount of sugar, mostly beet sugar, but have a 33 percent share in export of refined sugar and 60 percent share in export of sugar confectionery. These examples suggest that although DCs continue to be the main producers of products such as coffee, tea, cocoa, tobacco, rubber and sugar, in primary form, while the bulk of the processing for manufacture of roasted or instant coffee, cocoa powder/paste, tobacco and rubber products, and 
refined sugar remains concentrated in more developed countries. The importance of encouraging DCs' diversification into higher value-added production has been long discussed in the literature and in international fora. The point that is made is that if DCs specialise in exports of agricultural primary products, they are deprived of the income advantages that global value chains enjoy, as well as of additional employment opportunities and growth in value-added industries. A question relevant from a policy perspective is: why have DCs failed to capture a larger share of world exports of agricultural processed products? The reasons for this can be many. The underlying factors that exercise significant negative effects include the business climate, lagging technology, limited production capacities and intrinsic supply-side constraints, all of which contribute to curtailing the ability of DCs to diversify into processed product exports. The supply-side constraints in DCs include the poor quality of infrastructure (roads, electricity, communications) and institutions (legal, financial, regulatory), information bottlenecks, inadequate access to finance and governance issues (Moïsé et al., 2013). Some of these constraints are more severe for processed products compared to agricultural primary products.

The terms 'non-tariff measure' (NTM) and 'non-tariff barrier' (NTB) are often used interchangeably but are quite different. The term NTM simply identifies the measure whereas the term NTB indicates that the measure is trade-restricting. The objective of this paper is to identify the extent to which NTMs constitute market access barriers that thwart diversification efforts of DCs into value-added agricultural processed exports. The analysis highlights that it is the NTMs in developed countries as well as in DCs' themselves that limit DCs' ability to diversify into processed agricultural exports. This has important policy implications in terms of the emphasis that trade negotiators and policy planners should place on addressing non-tariff measures both in the domestic and foreign markets.

\section{NTMs in agriculture}

While tariffs, quotas and subsidies on agricultural products have declined since the early 1990s as a result of successive rounds of global trade liberalisation and signing of preferential trade agreements, NTMs have increased in numbers and complexity reflecting not only trade-related measures but also changing commercial practices, consumer and health concerns, improved scientific knowledge, and advances in technology and communications. Both public and private standards are increasingly influencing the production and trade of agricultural goods, and attention is therefore being given to addressing unjustified measures that may offset the advances brought about by lower tariffs.

NTMs in agri-food markets are policy measures, other than ordinary customs tariffs, that can potentially have an economic effect on international trade in agricultural goods, changing quantities traded or prices or both (MAST 2008). Within this broad definition of Organisation for 
Economic Co-operation and Development (OECD), three categories form the core of interventions commonly felt to be on the rise worldwide:

- Sanitary and phytosanitary measures (SPS): Regulations that protect human and animal health (sanitary measures) and plant health (phytosanitary measures) in order to ensure food safety for consumers and to avoid the introduction of diseases and pests through trade.

- Technical barriers to trade (TBT): Regulations and mandatory standards that target technical characteristics of products, such as process and product standards (include norms for size, quality and physical attributes of product), labelling and marketing standards, traceability and origin of material, and the related conformity assessment and certification.

- Other technical measures: Policies and requirements which somehow did not fit into the previous two categories but look quite similar to them for analytical purposes.

Typically, standards are used to address information problems, market failure externalities, or may be motivated by political considerations (for example, to satisfy demands of risk-averse and quality-conscious consumer behaviour in developed countries) or to promote economic, industrial and regional development as well as protect specified sectors from imports generally or from the dumping of cheaper imports. In the context of agri-food trade, they aim to ensure food safety, animal and plant health, but also extend to other quality and technical aspects of food products.

To the extent that NTMs address market failures, simply removing them may not always be optimal, even if trade volumes would increase, since their intended benefits would be sacrificed, for example those related to human health (SPS measures). Many technical measures may restrict trade but improve welfare through a reduction in negative externalities (e.g. through reduced risk of importing pests or diseases) or information asymmetries (e.g. through a label providing consumers with details on the product). It has been argued that standards and regulations can be perceived to act as a catalyst to upgrade DCs' processing industries production structures to make them compatible with international standards (Henson, 2006). In some instances NTMs can expand trade as they enhance demand for a good through better information about the good or by enhancing the good's characteristics and attractiveness for the consumer (Van Tongeren et al., 2009). Efficiency costs of NTMs are therefore much less evident than the welfare losses associated with tariffs and quantity measures that restrict trade. Analysis and policy must therefore respect these benefits, assess alternative ways to address the market failures, and assess NTMs on a caseby-case basis (Van Tongeren et al., 2010).

The most common types of NTMs in agricultural products are attributed to differences in technical and SPS standards between the exporting and importing country as well as diverging standards and specifications across different importing countries. In particular, these include specific measures to regulate product characteristics, marking, labelling, packaging, testing and SPS measures. Such measures constitute a trade barrier particularly if standards are designed and 
implemented, intentionally or otherwise, in a way that favours the production methods of a particular country or those of advanced countries. The literature shows a growing concern about certain regulations associated with environmental, national security and labour standards in developed-country markets. While these seem to be legitimate areas for regulation, bioterrorism rules, child labour clauses, and environment standards are mostly perceived in DCs as being more trade restrictive than necessary to achieve intended goals.

The European Commission funded project (2009 - 2011) 'Assessment of the impacts of non-tariff measures on the competitiveness of the EU and selected trade partners' (referred to as the NTMImpact project) analyses data on NTMs for key agri-food products that are most commonly traded by the EU with selected nine countries. A key finding of the project is that trade is significantly reduced when importing countries have stricter and/or differing standards (SPS or TBT) than the exporting countries. For example, important differences among standards applied in different industrialised countries in areas such as aflatoxin content or pesticide residues can increase the compliance cost particularly for developing exporting countries. The findings suggest that, at least for some import standards, the harmonization of regulations will be trade-increasing (Orden et al., 2012).

An NTM often reported on agricultural products by DC manufacturers in exporting countries is compliance with the EU regulation on traceability, which entered into force in January 2005 and requires all exporters to identify the origin of products. This imposes an additional cost burden on DC exporters as the domestic regulations do not require traceability in the supply chain. Small and medium sized enterprises, which form the bulk of producers and processors in DCs, face particular challenges. Those companies often lack the internal capacity and the economies of scale to establish effective quality assurance and traceability systems (Giovannucci \& Purcell, 2008). Thus, unless these sectors can make standard compliance cost effective and guarantee traceability for the buyers, many producers and processors will be increasingly marginalised and excluded from competitive markets both regionally and internationally with consequences for trade and economic growth.

From the above it emerges that not only are agricultural standards different and generally more stringent in developed countries compared to DCs, and at times more restrictive than those specified by the Codex Alimentarius (FAO, 2004), but also that they differ across developed countries. This adversely affects DCs' agricultural exports to developed countries, more so in the case of processed agricultural exports that require a greater degree of formal manufacturing and therefore higher effort and capabilities to fulfil standards. Therefore, the simplification and harmonisation of standards through international collaboration can be expected to promote DCs' agricultural processed exports. 
In addition to agricultural standards set and implemented by government authorities, an increasing number of agricultural trade standards is set by private groups or firms (retailers and agri-food companies). These standards, at times called private voluntary standards (PVS), usually apply to such areas as quality, process management, packaging requirements, or social concerns. They mainly reflect specific commercial needs such as value chain management, or the need to reduce the importing firm's exposure to risk. They are often implemented faster and usually have a larger scope or require higher levels of performance than the mandatory public standards and, as they evolve more rapidly than government regulations, they can be more difficult to follow and implement. Although voluntary, they are becoming the basic de facto entry requirement for trade with many of the large-scale operators and leading production and distribution chains; so for agrofood exports both public and private requirements are important (OECD, 2013).

Although standards going beyond basic entry requirements can represent important opportunities for increased market share or price for many agricultural products, they can also entail significant challenges for developing country producers and exporters faced with capacity and resource constraints. The heterogeneity of these standards entails collecting and evaluating relevant information and data on the applicable requirements, a complex operation, for which DC producers and exporters may be poorly prepared. In contrast, developed country producers and exporters who are better equipped to meet the standards will be in a better position to exploit market opportunities. A related problem is the requirement for internationally accredited agencies to certify many standards. This requirement particularly increases total costs for DC exporters as many of these agencies are based in developed countries, and certificates usually have to be renewed every year.

\section{Review of relevant NTM studies}

It is a challenging task to identify incidences of NTMs and to measure the degrees of trade restrictiveness they cause as well as the consequential economic and welfare impacts. The main challenges are related to issues concerning lack of data, data collection and measurement. The lack of transparency concerning the scope and effects of NTMs makes it very difficult to quantify the coverage and extent of these measures. Moreover, the analysis of NTMs often requires some kind of matching up of data of different classification and sources which makes it problematic (Korinek et al,.2008). Nevertheless, a host of studies employ different analytical approaches to detect NTMs and quantify their impact on trade and economic welfare in general. Some studies are based on overviews and assessments or deductions of NTMs, while others use economic models such as gravity-type models, price-wedge models, simulation and primary data analysis to measure the extent of trade restrictiveness of NTMs. This section presents the findings of some studies on NTMs. Although these findings suffer from the data limitations mentioned above and do not explore potential impacts for processed agricultural products, they are presented because they do call attention to key points. 
In general, the incidence of NTMs is higher on agriculture tariff lines than on manufactured products. Figure 1 shows the overall trade restrictiveness index (OTRI) based on the estimation of ad valorem equivalents of NTMs faced by exports for high, middle and low income countries. Large differences in the restrictiveness of NTMs are observed between agricultural and manufacturing products, with NTMs substantially adding to the level of restrictiveness faced by agricultural exports (OECD, 2013).

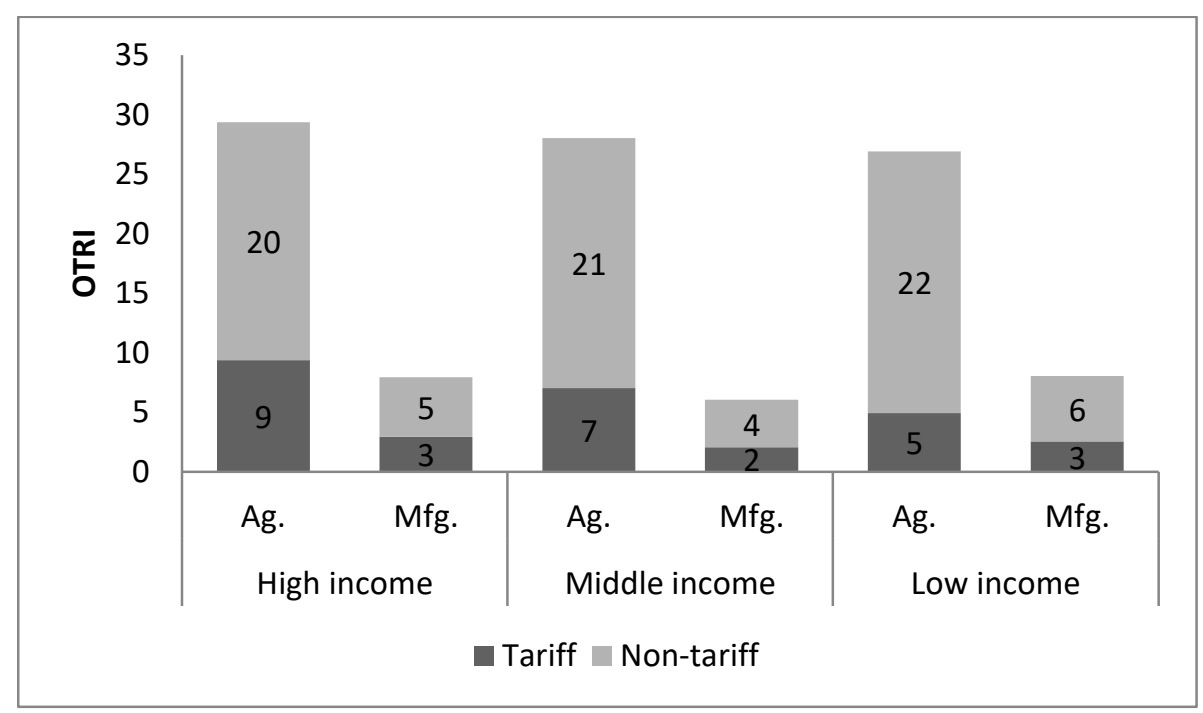

Figure 1. Overall level of trade restrictiveness faced by exports Source: UNCTAD, 2015

Francois et al. (2011) use a global CGE model of the world economy to examine the impact of EU preferential trade agreements (PTAs) with its OECD and G20 trading partners. The PTAs are modelled as involving elimination of tariff barriers and a 50 percent reduction in estimated NTMs for industrial goods (excluding energy goods): processed foods, chemicals, metals and metal products, motor vehicles, machinery, other manufactures. Table 2 presents the estimated impact on GDP of these changes. Consistently, the impact of NTM reductions is greater (2 to 3 times) than tariff elimination. The finding highlights the increasing importance of NTMs and points towards a shift in emphasis in PTAs from tariffs to deeper modes of integration, as these are more likely to address the impact of NTMs on exporters.

Disdier and Marette (2010) analyse the impact of NTMs notified by importing countries to the WTO under the SPS and TBT agreements on bilateral/multilateral trade flows. They focus on OECD imports of agricultural and food industry products (690 products at HS 6-digit level) from 114 exporting countries (OECD and others) for the year 2004, excluding intra EU trade. Their results suggest that SPS and TBT measures have on the whole a negative impact on trade in agricultural products. 
Table 2: Change in GDP, percent

\begin{tabular}{llll}
\hline & All PTAs together & Impact of tariffs & Impact of NTMs \\
\hline Japan & 0.80 & 0.21 & 0.59 \\
Korea & 2.29 & 0.79 & 1.50 \\
Canada & 0.34 & 0.02 & 0.32 \\
USA & 0.46 & 0.08 & 0.38 \\
Argentina & 0.99 & 0.19 & 0.80 \\
Brazil & 1.57 & 0.61 & 0.96 \\
India & 1.18 & 0.38 & 0.80 \\
Indonesia & 1.09 & 0.37 & 0.72 \\
Thailand & 1.39 & 0.33 & 1.06 \\
France & 0.73 & 0.18 & 0.55 \\
Germany & 1.01 & 0.27 & 0.75 \\
UK & 1.00 & 0.26 & 0.74 \\
\hline
\end{tabular}

Source: Francois et al. (2011)

Within the agricultural sub-sectors they find the trade-impeding impact of SPS and TBTs is the most severe for cut flowers and for processed food like beverages. They also show that OECD exporters are not significantly affected by these measures in their exports to other OECD members. On the other hand, exports of developing and least developed countries to OECD countries are significantly reduced by these regulations. Their results also show that EU countries in general notify less SPS and TBTs compared to other OECD countries, but their measures are more tradeimpeding (offering better protection) than the ones adopted by other OECD countries. Their results are robust to different econometric specifications.

Fontagné et al. (2005) collect data on 61 product groups, including agri-food products to analyse the stringency of the NTMs that countries may adopt. They focus on the measures covered under the WTOs Agreements on SPS and TBT. They find that the measures have a negative impact on agri-food trade but not on trade in other products. The measures significantly reduce DCs' exports to OECD countries, but do not affect trade between OECD members. Rather, OECD agri-food exporters tend to benefit from NTMs at the expense of exporters from DCs and LDCs. They also find that the negative trade effects are more prominent for pork meat, vegetables, wheat pastry as well as for a variety of processed agri-food products (e.g. chocolate, beverages).

\section{Analysis of NTMs data and business survey}

The UNCTAD TRAINS database records incidences of NTMs that are notified to the WTO as well as changes and new regulations with regards to the measures that apply to imports. The respective WTO notifications are documented by the type of measure (TRAINS category of technical measure) according to product (HS product codes) and notifying country from the year 
1992. The TRAINS database relies on self-reporting by WTO member countries. The TRAINS database shows that the governments of OECD countries impose requirements on almost all agrofood products except for some unprocessed products. Amongst the NTMs notified the marking, labelling and packaging requirements are most frequently reported, followed by requirements for product characteristics, followed by testing, certification and conformity requirements. Although these requirements affect all agricultural products, they are likely to affect agricultural processed products even more or at the most equally. NTMs notified for agricultural products by OECD countries are in Table 3.

Table 3: NTMs notified for agricultural products by OECD countries

\begin{tabular}{lr}
\hline NTMs & Share (\%) \\
\hline Labelling, packaging \& marking requirements & 39 \\
Product characteristics requirements & 28 \\
Testing, inspection and quarantine requirements & 25 \\
Technical regulations & 5 \\
Information requirements & 3 \\
Total & 100 \\
\hline
\end{tabular}

Note: Data excludes sensitive products

Source: UNCTAD TRAINS database

As part of a European Commission project (ECORYS, 2009) business surveys were conducted of EU firms exporting and importing goods within the EU and with the US and G20 firms. The firms were chosen (over 6000 firms) who had substantial trading interest (i.e., annual exports and imports valuing about 30 per cent of their turnover). The survey results (about 5000 firms) are used to attain NTM indexes for processed foods sector using the Anderson et al. (2009) method, the indexes in turn are used to compile the equivalent trade cost of NTMs. The logic or assumption is that the trade costs of NTM are because of differences in regulations and their implementation between trading countries. The common market of the EU has achieved harmonisation of regulations that are recognised by all EU countries and firms. Therefore it can be treated as a benchmark of the minimum that can be achieved in terms of reduction in NTM-related trade costs. The trade cost equivalents of NTMs are calculated from the gap between the NTM indexes for transactions of EU firms with other EU firms and those of EU firms with other OECD and G20 countries.

Table 4 shows estimates of NTMs trade costs for processed food for selected countries. The values show the net addition to the cost of delivery because of NTMs for cross-border consumers. For example, NTMs add an estimated 30 percent to the cost of delivery of processed foods to the EU from countries outside the EU, while that for the US is 50 percent. As shown in Table 4 NTMs for 
processed products are very high and thus important in obstructing trade. These products face tariffs as well, but these have come down over the years because of commitments for reduction in MFN tariffs under the WTOs Trade Rounds, in particular tariffs across most products have gone down substantially over the years for OECD countries. However, the same cannot be said for NTMs, which explains the need for greater attention to NTMs by countries and trade negotiators. Moreover, while tariffs are collected as government revenue, they do not result in substantial increases in the actual cost of production/delivery unlike NTMs which do result in increases in these costs. A range of studies use Computable General Equilibrium (CGE) modelling to simulate the potential impact if countries implement tariff reduction on an MFN basis. Although the results of these studies are based on assumptions such as price elasticities of demand, in general the simulation results from most of these studies show that a tariff reduction by 50 percent on an MFN basis can be expected to increase exports by around 15-20 percent. If we apply this result, for example to the United States, it can be expected that a 50 percent reduction in NTM trade costs will result in about 15 percent increase in processed food exports to the United States.

Table 4: Processed foods NTM trade costs (percent of import value)

\begin{tabular}{lc}
\hline Country & Trade costs \\
\hline United States of America & 50 \\
European Union & 30 \\
Canada & 23 \\
Russia & 65 \\
China & 45 \\
\hline
\end{tabular}

Source: EU and OECD databases

The International Trade Centre initiated a series of surveys to document NTMs that exporters in developing countries perceive as problematic. Surveys have been conducted in more than 11,500 companies in 23 developing countries, covering all major exports. The survey findings show that the agro-food sector is particularly impacted by NTMs, particularly the highly perishable fresh food sector with the overall exporters' affectedness by NTM-related trade obstacles above 60 percent. The second most impacted sector is processed food, with 55 percent of exporters declaring being affected. For agricultural products in general, developed countries are perceived as comparatively more NTM-restrictive than other markets. Table 5 lists the main NTMs reported by companies in the agro-food sector, which shows the highest number relate to conformity assessment (such as rules of origin, traceability, testing, inspection and certification) followed by product-related requirements (such as labelling, packaging, technical and SPS) set by the importing country. Some firms commented that technical regulations and standards applied by certain developed countries are more stringent than those specified by relevant international bodies, and the justification for this is not explained. 
Table 5: NTMs notified by processed food exporting firms

\begin{tabular}{lc}
\hline \multicolumn{1}{c}{ NTM type } & $\%$ share \\
\hline Customs \& administrative procedures (including traceability \& rules of origin) & 21 \\
Labelling \& packaging requirements & 10 \\
Testing \& certification arrangements & 11 \\
Other Technical regulations \& standards & 8 \\
Sanitary \& Phytosanitary measures & 5 \\
\hline
\end{tabular}

In summary, the findings from the NTMs data analysis and review of studies call attention to the following key points:

- The incidence of NTMs is higher on agriculture tariff lines than on manufactured products.

- Within agriculture, highly perishable fresh food products appear as most impacted by NTMs followed by processed food.

- NTMs add an estimated 30 percent to the cost of delivery of processed foods exported to the EU.

- For agricultural products in general, developed countries are perceived as comparatively more NTM-restrictive than other markets.

- Most of NTMs in agriculture (more than 40 percent) relate to control and administrative procedures (categorised as conformity assessment).

- NTMs significantly reduce DCs' agricultural exports to OECD countries, but do not affect trade between OECD members (rather, OECD agri-food exporters tend to benefit from NTMs at the expense of exporters from DCs).

\section{Domestic NTMs in DCs}

In addition to NTMs in foreign markets, there are domestic NTMs to trade in DCs that impede exporting activity (Cadot \& Gourdan, 2012). The common perception is that NTMs are faced in the destination market. More than 25 percent of reported problems correspond to measures applied by the home country of the exporting company. An important category of problems faced at home by exporters is procedural obstacles. The second most important problem concerns red tape and corrupt practices. The WTO categorises them as trade facilitation issues such as excessive customs documentation, import and export requirements, lack of cooperation among customs and other government agencies, inadequate use of information technology, information asymmetry and lack of transparency. These domestic NTMs increase transaction costs of exports, which adversely affects export competitiveness. We look at two sets of procedures - documentary compliance and border compliance - within the overall process of exporting or importing a shipment of goods. Table 6 reports for selected regions and developed and DCs the round of data collection for the project which was completed in June 2015. 
Table 6: Doing business - trading across borders

\begin{tabular}{|c|c|c|c|c|c|c|c|c|}
\hline Name & $\begin{array}{l}\text { Time to } \\
\text { export: } \\
\text { Documentar } \\
\text { y } \\
\text { compliance } \\
\text { (hours) }\end{array}$ & $\begin{array}{l}\text { Cost to } \\
\text { export: } \\
\text { Documentar } \\
\text { y } \\
\text { compliance } \\
\text { (USD) }\end{array}$ & $\begin{array}{l}\text { Time to } \\
\text { export: } \\
\text { Border } \\
\text { complianc } \\
\text { e (hours) }\end{array}$ & $\begin{array}{l}\text { Cost to } \\
\text { export: } \\
\text { Border } \\
\text { complianc } \\
\text { e (USD) }\end{array}$ & $\begin{array}{l}\text { Time to } \\
\text { import: } \\
\text { Documentar } \\
\mathrm{y} \\
\text { compliance } \\
\text { (hours) }\end{array}$ & $\begin{array}{l}\text { Cost to } \\
\text { import: } \\
\text { Documentar } \\
\text { y } \\
\text { compliance } \\
\text { (USD) }\end{array}$ & $\begin{array}{l}\text { Time to } \\
\text { import: } \\
\text { Border } \\
\text { complianc } \\
\text { e (hours) }\end{array}$ & $\begin{array}{l}\text { Cost to } \\
\text { import: } \\
\text { Border } \\
\text { complianc } \\
\text { e (USD) }\end{array}$ \\
\hline \multicolumn{9}{|l|}{ Regions } \\
\hline OECD high income & 5 & 36 & 15 & 160 & 4 & 25 & 9 & 123 \\
\hline South Asia & 80 & 184 & 61 & 376 & 108 & 349 & 114 & 653 \\
\hline Latin America & 68 & 134 & 86 & 493 & 93 & 128 & 107 & 665 \\
\hline Sub-Saharan Africa & 97 & 246 & 108 & 542 & 123 & 351 & 160 & 643 \\
\hline \multicolumn{9}{|l|}{ Developed countries } \\
\hline Australia & 7 & 264 & 36 & 749 & 3 & 100 & 37 & 525 \\
\hline Germany & 1 & 45 & 36 & 345 & 1 & 0 & 0 & 0 \\
\hline Japan & 3 & 15 & 48 & 306 & 3 & 23 & 48 & 337 \\
\hline United Kingdom & 4 & 25 & 24 & 280 & 2 & 0 & 8 & 205 \\
\hline United States & 2 & 60 & 2 & 175 & 8 & 100 & 2 & 175 \\
\hline \multicolumn{9}{|l|}{ Developing countries } \\
\hline Brazil & 42 & 226 & 49 & 959 & 146 & 107 & 63 & 970 \\
\hline China & 21 & 85 & 26 & 522 & 66 & 171 & 92 & 777 \\
\hline Colombia & 60 & 90 & 112 & 545 & 64 & 50 & 112 & 545 \\
\hline Egypt, Arab Rep. & 88 & 100 & 48 & 203 & 192 & 650 & 120 & 1383 \\
\hline Ghana & 89 & 155 & 108 & 490 & 282 & 302 & 282 & 725 \\
\hline India & 41 & 102 & 109 & 413 & 63 & 145 & 287 & 574 \\
\hline Indonesia & 72 & 170 & 39 & 254 & 144 & 160 & 99 & 383 \\
\hline Sri Lanka & 76 & 58 & 43 & 366 & 58 & 283 & 72 & 300 \\
\hline Zambia & 130 & 200 & 136 & 370 & 134 & 175 & 139 & 380 \\
\hline
\end{tabular}
Source: World Bank 
The longer time and higher cost needed to arrange exports from DCs reflects a relatively higher level of domestic NTMs for DCs' exporters compared to developed countries' exporters. Furthermore, most export products have a component of imports, so ease of importing facilitates exports. Therefore, the requirement of longer time and higher cost to arrange imports also amounts to domestic NTMs for DCs' exporters

Although domestic NTMs impact all exports from DCs, the adverse impact for processed agricultural exports from DCs can be relatively high as DCs have to compete with developed countries. This is not the case for many primary products (such as coffee, cocoa, tea, tobacco, rubber and cane sugar) for which competition is among DCs that face more or less similar levels of domestic NTMs.

\section{Conclusions and policy implications}

The objective of this paper is to understand why DCs perform poorly in agricultural processed product exports despite being the main producers of many of these products in their primary form. The evidence clearly points to the widespread prevalence of NTMs in developed countries that impact on trade of processed agricultural products and that have relatively more severe effects in restricting market access for these products from DCs.

These conclusions have important policy implications in terms of the effort that trade negotiators and policy planners need to make to manage and reduce these barriers, particularly those that unjustifiably curtail trade. The analysis also highlights that domestic NTMs are an important trade barrier for DCs' agricultural processed product exports. This is an area where DCs must act urgently if they want to compete with developed countries. The potential benefits from lowering domestic NTMs appear to be large, as this could add considerably to the export potential of DCs by lowering the transaction costs of their exports. This again has important policy implications in terms of the effort that individual DCs policy planners need to make to lower these barriers.

It should be stressed that the analysis nowhere suggests that NTMs are the only or the main cause of the inability of DCs to capture a larger share of agricultural processed product world exports. The reasons for this failure can be many, in particular the intrinsic supply-side constraints in DCs limiting their ability to diversify into processed product exports. Moreover, there may be some comparative advantage associated with processing in developed markets. If developed markets are major consumers of the final (processed) products, an advantage of production being closer to the consumers is of adjusting production and marketing promptly to changing consumer preferences as well as meeting the requirements of supermarkets and retailers. Another advantage is of access to primary product from more than one origin. For example, most of the popular coffee and tea retail brands are blends that use coffee and tea from different origins in different proportions. 
Arguably some of the above-mentioned advantages of processing in developed consuming markets can be countered by DCs' advantages in areas such as cheap skilled and unskilled labour. The balance of advantage for individual products can be ascertained only on the basis of careful review and evaluation.

Notwithstanding the above, lowering NTMs does offer a dynamic opportunity for many DCs to increase exports of agricultural processed products both to developed and developing country markets, in particular for those agricultural products that in their primary form are mostly produced in DCs. An important dimension of agricultural trade liberalisation is the need to ensure that the issue of NTMs is high on the agenda of developing country trade negotiators and that DCs pay more attention to addressing their domestic NTMs, particularly streamlining the process of exports and imports to reduce time and transaction costs of exporting and importing. With a high share of agriculture in gross domestic product and in exports, the costs associated with complying with NTMs in agriculture have a relatively higher overall economic impact in DCs than in high-income countries.

Undoubtedly there is need for greater policy coherence with regard to NTMs. To the extent NTMs relate to changing commercial practices, health and safety concerns, and technological advances, they are most likely to stay. It should also be kept in mind that good regulation can also facilitate trade and development. This explains the need for greater attention to NTMs by countries and trade negotiators. The challenge remains to separate protectionist and non-protectionist measures and to identify alternative policies that are less onerous for trade. More attention should be given to identifying NTMs that are of particular concern to DCs agricultural processed exports so as to help determine priority targets for strengthening special and differential treatment (SDT) as well as international collaboration in the field of NTMs. DCs too should step up their efforts to implement domestic policies that assure compatibility with international standards and assist agricultural processors and producers in meeting the required standards and regulations for exports.

\section{References}

Aksoy, M.A. \& Ng, F. (2010). The Evolution of Agricultural Trade Flows. Policy Research Working Paper No. 5308, Washington, DC: Development Research Group, World Bank.

Anderson, J. E., Bergstrand, J. H., Egger, P. \& Francois, J. (2009). Non-tariff Barrier Study Methodology. Directorate General for Trade, Reference: OJ 2007/S 180-219493, 2009.

Beghin, J. \& Aksoy, A. (2003). Agricultural Trade and the Doha Round: Lessons from Commodity Studies. Briefing paper 03-BP 42, Ames, IA: Centre for Agricultural and Rural Development, Iowa State University.

Cadot, O. \& Gourdon J. (2012). Assessing the Price-raising Effect of Non-tariff Measures in Africa. Working Papers 2012-16, CEPII Research Center. 
Disdier, A. C. \& Marette S. (2010). The Combination of Gravity and Welfare Approaches for Evaluating Nontariff Measures. American Journal of Agricultural Economics, 92(3): 713-726.

ECORYS (2009). Non-Tariff Measures in EU-US Trade and Investment - An Economic Analysis. Report prepared for European Commission, Directorate-General for Trade, Reference: OJ 2007/S 180-219493

FAO (2004). Worldwide Regulations for Mycotoxins in Food and Feed in 2003. Rome: FAO. FAOSTAT (2019). Database. Food and Agriculture Organization of the United Nations, Rome.

Fontagné, L., Mimouni, M., \& Pasteels, J-M. (2005). Estimating the Impact of Environmental SPS and TBT on International Trade. Integration and Trade Journal, 22:7-37.

Francois, J., Manchin, M. \& Norberg, H. (2011). European perspectives on NTM and tariff liberalization. ESRI Discussion Paper No. 265, Economic and Social Research Institute, Cabinet Office, Government of Japan, Tokyo.

Giovannucci, D. \& Purcell, T. (2008). Standards and Agricultural Trade in Asia. Asian Development Bank Institute, Discussion Paper, No. 107, Tokyo.

Henson, S. (2006). The Role of Private and Public Standards in Regulating International Food Markets. Paper presented at the IATRC Summer Symposium: Food Regulation and Trade Institutional Framework, Concepts of Analysis and Empirical Evidence, 28-30 May, Bonn.

Korinek, J., Melatos, M., \& Rau, M-L. (2008). A Review of Methods for Quantifying the Trade Effects of Standards in the Agri-food Sector. Paris: OECD.

MAST (Multi-agency support team) (2008). First Progress Report to the Group of Eminent Persons on Non-tariff Barriers. Geneva: UNCTAD.

Moïsé, E., Delpeuch, C., Sorescu, S., Bottini, N., \& Foch, A. (2013). Estimating the Constraints to Agricultural Trade of Developing Countries. OECD Trade Policy Papers, No. 142, OECD Publishing. http://dx.doi.org/10.1787/5k4c9kwfdx8r-en

OECD (2013). Non-Tariff Measures in Agri-Food Trade: Improving Policy Coherence for Development. Paris: OECD.

UNCTAD (2015). Non-Tariff Measures to Trade: Economic and Policy Issues for Developing Countries. Geneva: UNCTAD.

Van Tongeren, F., Beghin, J., \& Marette, S. (2009). A Cost-Benefit Framework for the Assessment of Non-Tariff Measures in Agro-Food Trade. OECD Food, Agriculture and Fisheries Working Papers, No. 21, OECD Publishing.

Van Tongeren, F., Disdier, A. C., Komorowska, J., Marette, S., \& von Lampe, M. (2010). Case Studies of Costs and Benefits of Non-Tariff Measures: Cheese, Shrimp and Flowers. OECD Food, Agriculture and Fisheries Working Papers 28, OECD, Paris.

\section{Author's Note}

The author thanks the FAO Trade and Markets Division for assistance with data collection and two anonymous referees for helpful comments. 
Appendix 1: The classification of agricultural products

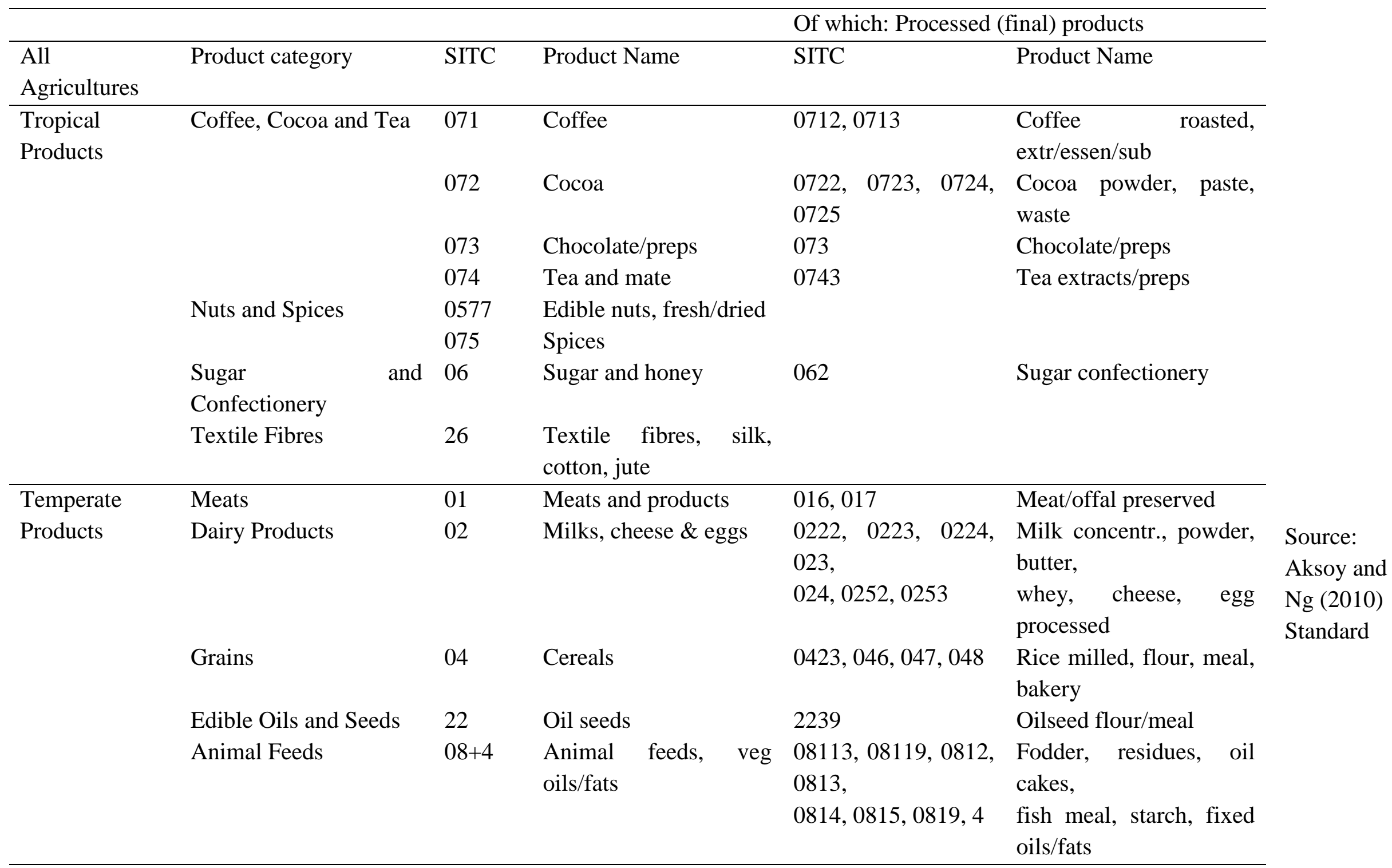

International (SITC 3) for separating the agricultural processed product 


\begin{tabular}{|c|c|c|c|c|c|}
\hline $\begin{array}{l}\text { Seafood, } \\
\text { Fruits and }\end{array}$ & Seafood & 03 & Fish, shell fish etc. & $\begin{array}{l}0353,0354,0355, \\
037\end{array}$ & $\begin{array}{l}\text { Fish, } \\
\text { preps/presv. }\end{array}$ \\
\hline Vegetables & $\begin{array}{l}\text { Fruits and Vegetables } \\
\text { Flowers \& Crude Veg } \\
\text { Material }\end{array}$ & $\begin{array}{l}05- \\
0577 \\
292\end{array}$ & $\begin{array}{l}\text { Fruits \& veg, excl. nuts } \\
\text { Cut flowers, roots \& } \\
\text { lac/gums }\end{array}$ & $0547,056,058,059$ & $\begin{array}{l}\text { Fruit \& veg presv/preps, } \\
\text { juices }\end{array}$ \\
\hline \multirow{3}{*}{$\begin{array}{l}\text { Other } \\
\text { Processed } \\
\text { Food }\end{array}$} & Tobacco & 12 & Tobacco /manufactures & 122 & Tobacco, manufactured \\
\hline & Beverages & 11 & $\begin{array}{l}\text { Beverages, } \\
\text { alcohol/non-alc }\end{array}$ & 111,112 & $\begin{array}{l}\text { Beverages, alcohol/non- } \\
\text { alcohol }\end{array}$ \\
\hline & Other Processed Food & 09 & Other food preps/sauces & 09 & Other food preps/sauces \\
\hline \multirow{6}{*}{ Agricultures } & Other Raw Agric. & & & & \\
\hline & Products & 00 & Live animals & & \\
\hline & & 21 & Hides and skins/fur & & \\
\hline & & 23 & Crude rubber, synthetic & & \\
\hline & & 24,25 & Wood/cork and papers & 251 & Pulp and waste paper \\
\hline & & 291 & $\begin{array}{l}\text { Crude animal \& veg } \\
\text { materials }\end{array}$ & & \\
\hline
\end{tabular}


